\title{
Memorial Boxes and Guarded Interiors: Edith Wharton and Material Culture
}

\author{
Gary Totten
}

Emily J. Orlando

Fairfield University, eorlando@fairfield.edu

Follow this and additional works at: https://digitalcommons.fairfield.edu/english-books

Copyright 2007 The University of Alabama Press.

Content has been archived here with the permission of the copyright holder.

\section{Recommended Citation}

Totten, Gary and Orlando, Emily J., "Memorial Boxes and Guarded Interiors: Edith Wharton and Material Culture" (2007). English Faculty Book Gallery. 4.

https://digitalcommons.fairfield.edu/english-books/4

This item has been accepted for inclusion in DigitalCommons@Fairfield by an authorized administrator of DigitalCommons@Fairfield. It is brought to you by DigitalCommons@Fairfield with permission from the rightsholder(s) and is protected by copyright and/or related rights. You are free to use this item in any way that is permitted by the copyright and related rights legislation that applies to your use. For other uses, you need to obtain permission from the rights-holder(s) directly, unless additional rights are indicated by a Creative Commons license in the record and/or on the work itself. For more information, please contact digitalcommons@fairfield.edu. 


\title{
5 \\ Picturing Lily \\ $\infty$ \\ Body Art in The House of Mirth
}

\author{
Emily J. Orlando
}

"By Jove, Lily, you do look a stunner!"

-Gus Trenor to Lily Bart, The House of Mirth

In The House of Mirth (1905), as in much of her earlier fiction, Edith Wharton pays considerable attention to the voyeuristic imaging of women as objects that inspire and arouse male desire. Wharton's novel, however, marks an important turning point in her fiction because of its response to the ways that "pictures" of women have been used in the popular imagination, and one of these surely was for sexual titillation. Lawrence Selden, the most devoted spectator of Wharton's Lily, invests considerable energy in enjoying and consuming his own pictures of Lily. The House of Mirth opens and closes, after all, with Selden gazing at the beautiful Lily Bart. And although the better part of the narrative is viewed through Lily's perspective, the novel favors Selden's gaze in the beginning, middle, and end. He is, in Wharton's words, a "spectator" (5) with a proclivity for "visionmaking" (215) who "had always enjoyed Lily Bart" (5). ${ }^{2}$ But Wharton's response to the role that spectacular pictures of women played in her culture-a response articulated most clearly in the tableaux vivants scene of book I-suggests a function that extends beyond titillation. That is, Wharton lets her Lily manipulate the power of imaging to her advantage by overseeing her objectification as a work of art.

While in such early Wharton tales as "The Duchess at Prayer" (1900) and "The Moving Finger" (190I) female protagonists are literally and metaphorically "enshrined" in art—and enshrining is but a euphemism for kill- 
$84 \curvearrowright$ Orlando

ing-Wharton's Lily is neither enshrined nor entombed by art, though Lily's body, of course, becomes a kind of shrine by the novel's end, due, in part, to her refusal to compromise, and this is a point to which we will return. Wharton draws from a different vocabulary to describe Lily's living picture. In fact, unlike in Wharton's earlier fiction, the word "shrine" (or its derivative) does not appear in the 1905 novel. Rather than be "shrined" in the way female bodies are captured in the art of Dante Gabriel Rossetti and his Pre-Raphaelite brothers, Lily Bart willingly "step[s], not out of, but into" (216) art, ${ }^{3}$ and while Wharton's earlier women find death in art, it is there that Lily finds life. After the curtain falls on her tableau, Lily is struck by "the completeness of her triumph" and "an intoxicating sense of recovered power" (219). But, as Wharton demonstrates, Lily's power is nevertheless unsatisfying in the grand scheme of things. Wharton thus identifies and critiques a rather unfortunate undercurrent in her culture that would have women eagerly become art for the amusement of their peers as well as for their own personal profit.

It already has been shown that Lily Bart offers herself, and is read by others, as a work of art. ${ }^{4}$ Wharton makes it clear Lily "had been fashioned to adorn and to delight" (486-87), and, as Lily herself knows, she is destined to barter her beauty on the marriage market. As Judith Fetterley has observed, the "movement from her mother's indoctrination to Lily's presentation of herself in the Wellington Brys tableaux as a living art object is as inevitable as it is frightening" (20I). It hardly surprises us that Wharton's Lily would seek and locate power in the one field for which she has been outfitted: body art. Her body becomes her art.

This essay recognizes The House of Mirth as a site where a Wharton heroine manages to find power in art- to let it work for, rather than against, her-and it argues that reading the novel within the art historical framework Wharton encourages allows us to acknowledge the progressive stance that Lily Bart's self-representation takes in Wharton's oeuvre. Lily locates power in turning herself into art in the tableaux vivants scene, which is the central focus of this discussion. Nowhere in the novel is Lily more powerful than when she poses as Sir Joshua Reynolds's Mrs. Lloyd and thereby oversees her objectification. The essay contextualizes Lily's tableau vivant within the tradition of the drawing-room convention, and it reads this moment alongside those episodes in Wharton's fiction in which women are seduced or enshrined in art. Perhaps most important, this essay 


\section{Picturing Lily $\propto 85$}

encourages a careful reading of Lily's selection for her tableau vivant. Lily's alignment with a painting by the quintessential academic painter for whom the Pre-Raphaelite Brotherhood (PRB) reserved its bitterest scorn ought to be read in keeping with Wharton's career-long argument with, and critique of, the oversexed palette of the PRB. While Judith Fryer has asserted, in her important essay "Reading Mrs. Lloyd" (I992), that Wharton's "knowledge of painting ... was not substantial" (34), the fiction suggests otherwise. This essay argues for the importance of situating Lily's tableau within this art historical context and reading it alongside the other "living pictures" Wharton has carefully lined up for her pageant. Further, it shows Wharton to have drawn again from her literary model, George Eliot, as a source for this pivotal scene. Contextualizing Lily's choice in this way helps us to place her in a continuum of Wharton women and to appreciate the revisionary work of The House of Mirth and the later fiction.

Although Lily has control over the imaging of her body and enjoys a relationship to art that an early Wharton heroine could not, she fails to escape the fate of the luckless ladies of the early fiction. While Lily attempts to barter her body with the goal of marriage in mind, her conscience interferes, ultimately costing her her life. In the case of Lily Bart, then, Wharton does not spare her heroine from the inextricable link between art and necrophilia that is fleshed out in such early tales as "The Duchess at Prayer" and "The Moving Finger." Turning to such later heroines as Undine Spragg of The Custom of the Country (I9I3) and Bessy Paul of "The Temperate Zone" (I924) allows us to see some of the choices available to women like Lily - the ways in which a young woman might avoid the status of the beautiful corpse. In the modern women of the later fiction, Wharton illustrates a kind of compromise by which women comply with the bartering of their bodies within the world of art.

These Wharton narratives collectively address the troubled topic of prostitution - that is, the bartering of one's body for profit. Lily prostitutes her body when she transforms herself into a work of art, displaying her beauty on the marriage market in hopes of procuring a husband. The double entendre of the phrase "painted lady" is especially apt to Lily's case, for in her tableau vivant she at once transforms herself into a painting of a lady (living picture) and a sort of painted lady (prostitute). Maureen Montgomery acknowledges the link between prostitution and the display of the female body and the risks this connection posed for society women. 
Similar to "an actress in the marketplace" or a commodity on display, " $[\mathrm{t}] \mathrm{he}$ demimondaine made herself into an object of desire and of luxury in order to appeal to a high-class male clientele," Montgomery observes, making it difficult for society women to "step out onto the public stage-into the fashionable streets, the Park and the opera-and exhibit themselves without running the risk of being misrecognized" (120).

Although Lily runs such a risk by displaying her body in the tableaux vivants scene, when her safety and security are most threatened, she refuses to compromise. For example, Lily will not accept marriage to a man she finds undesirable in order to put food on her table, at the very least, and to maintain the society life for which she has been bred, at the very best. However, a number of Wharton's later women "prostitute" their bodies to support themselves financially. Their prostitution is a survival tactic, and in their example Wharton offers a way to seize control of one's own objectification. These women take charge of their bodies and their images, putting both into circulation. They also make socially acceptable marriages, which is one reason they survive and Lily does not. With the examples of Lily's younger literary sisters, Wharton would increasingly suggest that women can strategically use their bodies to survive.

Wharton offers in her fiction several portraits of compromising women who, like the seasoned heroine of "The Quicksand" (1902), are painfully aware that "[l]ife is made up of compromises," for "women especially" (I7). In the early "The Muse's Tragedy" (1899), the heroine breaks free of her objectification in art only to live a disappointed life. Undine Spragg of The Custom of the Country oversees the circulation of her image and her body but remains restless and dissatisfied by the time we leave her. In Wharton's novella New Year's Day (1924), Lizzie Hazeldean accepts the title of "expensive prostitute" in order to support herself and her dying husband (II4). Like more than one Wharton heroine, Lizzie is relegated to a life of "cold celibacy" (152). In The Gods Arrive (1932), her last completed novel, Wharton presents us with another compromising (and compromised) woman: Halo Tarrant would willingly serve her lover as a muse and subsume her identity for his professional gain. And while Ellen Olenska of The Age of Innocence (1920) escapes alive the oppression of Old New York, moves to France, and establishes there an autonomous, artistic life, she, too, makes sacrifices in the name of freedom. Wharton thus critiques a culture that affords women so few opportunities for independence and satisfaction that 


\section{Picturing Lily $\propto 87$}

they are compelled to compromise their virtue, their freedom, their self-respect, or all of the above. But at the same time Wharton interrogates and explores the possibilities for women and the ways in which they might, at the very least, escape being killed into art and secure for themselves some kind of power. One thing seems fairly certain: the reason the later heroines survive and Lily Bart does not is because of a willingness, in the final hour, to compromise one's virtue, one's body, one's beauty, or one's freedom, all in the name of survival.

The tableau vivant or "living picture," which enjoyed a revival in the nineteenth century as a kind of parlor game for the leisure class, has a colorful history that predates Wharton's day. Its origins can be found in the pageants and royal processions of the Renaissance and in the eighteenthcentury example of Emma, Lady Hamilton, who, as Richard Altick notes, was known for her pantomimed "attitudes" impersonating such classical women as Helena, Cassandra, and Andromache (344). Tableaux vivants have a historical connection to the theatre: they were staged between the acts of eighteenth-century Parisian theatrical performances (Fryer, "Reading Mrs. Lloyd" 29), and, as Jack McCullough notes, they made their New York debut during the $183 \mathrm{I}-32$ theatre season (II). George C. D. Odell noted that Mrs. Ada Adams Barrymore, one of the early tableaux vivants performers, enacted "a new form of art, the reproduction of famous pictures in living tableaux" (qtd. in McCullough II). The players who enacted tableaux were called "model artists" (19), ${ }^{6}$ a term that points to their dual classification as both models (still, frozen bodies) and artists (makers of art).

Rather coincidentally, one of the ways in which American culture was introduced to these model artists and their tableaux vivants was through a theatre company overseen by a Madame Warton. An I840s playbill for the London-based company lists the reenactment of paintings by such artists as Sir Joshua Reynolds, Angelica Kauffman, Nicolas Poussin, and Correggio (McCullough 43, fig. 8), all of whose works make appearances in Wharton's fiction. In fact, images by Reynolds and Kauffman are brought to life in the tableaux vivants scene in The House of Mirth. The performances listed on the playbill for Madame Warton's troupe pay homage to such classical themes as the Judgment of Paris and such figures as Diana and "Venus Rising from the Sea," both of which, the playbill indicates, were impersonated by Madame Warton herself.' Diana of the chase and Venus rising from the foam make cameos in Wharton's novels; for example, 
May Welland of The Age of Innocence is repeatedly likened to Diana, and Norma Hatch of The House of Mirth is described as rising "like Venus from her shell" (44I). Madame Warton's troupe of performers came to New York's Franklin Theatre (renamed the Franklin Museum) in 185I (McCullough 38). An 1858 playbill for the Franklin Museum advertises Madame Warton's "New Troupe of Model Artistes" in a series of tableaux and boasts the presentation of "Living Statuary" devoted to such topics as "Innocence," "The Three Graces," and "Diana preparing for the Chase" (McCullough 47 , fig. 10). It is worth noting that Madame Warton was re-creating, in the I840s, the very sort of neoclassical art against which the Pre-Raphaelite Brotherhood was rebelling in the same city and the same decade. Turning to this historical precedent helps us position Wharton as a director of a kind of stage show for her readers, and it also suggests she likely was both aware of her British predecessor and amused by the thought of casting herself, half a century later, as the American Madame W[h]arton, mistress of the tableau vivant.

Most tableaux vivants were sensational in nature and designed to titillate. George Foster noted in 1850 that " $[\mathrm{u}] \mathrm{p}$ to this time these exhibitions had been composed exclusively of men, and we never heard of their being immodest; but the moment the ladies made their appearance, an outcry of outraged public decency rose on all sides" (qtd. in McCullough 19). As soon as the viewer's gaze shifted to female bodies on display-and scantily clad at that - the tradition became associated with indecency. Judith Fryer has noted the risqué nature of these performances: " $\mathrm{t}]$ hese presentations drew a mixed public reaction in the latter half of the nineteenth century: on the one hand, respectable audiences... [were] given 'permission' to stare at women in a state of semi-nudity (often the only covering would be paint sprayed on the body) under the guise of viewing 'great art' . . ; on the other hand, certain segments of the population, such as the WCTU [Women's Christian Temperance Union], were outraged by the indecent displays" ("Reading Mrs. Lloyd" 30). ${ }^{8}$ A late-1840s movement that sought to suppress this trend was unsuccessful (McCullough 36), and events such as the arrival of Bartholdi's Statue of Liberty in New York in the 1880 s continued to provide new tableaux subjects (98).

In nineteenth- and early-twentieth-century America, tableaux vivants thrived in both the private and public sphere. According to Russell Lynes, between 1860 and 1890 , middle-class evening parties were structured around 


\section{Picturing Lily $\propto 89$}

the depiction of tableaux, many of them inspired by John Rogers's sentimental statuettes (74). In the 1890 os theatre scene the convention reached new heights and was dominated by Edward Kilianyi, whose living pictures, titled "Queen Isabella's Art Gallery," drew crowds to the show 1492, and whose career was built on his mastery of this genre (McCullough IOI). The Illustrated American magazine of October 1895 noted how tableaux vivants "took the country by storm" in the I89os (qtd. in Fryer, "Reading Mrs. Lloyd" 3I) - the culture's affinity for spectacle makes it easy to see whybut their appeal (and necessity) eventually was eclipsed by the advent of motion pictures.

By virtue of invoking the drawing-room version of the tableau vivant, Wharton looks back to George Eliot's Daniel Deronda (1876), whose heroine, Gwendolen Harleth, strikes a pose as the pure and beautiful martyr Saint Cecilia. One of Eliot's great admirers, Wharton likely is responding to the earlier writer's use of tableaux. But Lily does not choose, for her "living picture," to embody a virgin or martyr such as Saint Cecilia, who, as patron saint of music, repeatedly is depicted in the visual arts and poetry as sleeping or swooning. Further, Lily resists aligning herself with the kind of frozen terror personified in Gwendolen's tableau of Hermione. Lily certainly had at her disposal many a passive, disempowered beauty to impersonate: she might, for example, align herself with John William Waterhouse's 1895 painting of the pale, sleeping Cecilia or Rossetti's renderings of the swooning saint produced for the Moxon Tennyson volume. Whether asleep or unconscious, the female subject's eyes are closed, which invites the spectator's to linger all the more, confident her gaze will not answer back.

Sleeping women saturated nineteenth-century visual culture. Painters were obsessed with depicting women as beautiful, unmoving bodies reclined in passive purity, presumably waiting patiently for their suitors to awaken them. In Angels of Art, Bailey Van Hook documents this trend of depicting women in languid poses: "Paul Baudry's The Pearl and the Wave...., Cabanel's The Birth of Venus..., Leighton's Flaming June, and Albert Moore's Beads... were some of the more famous examples of females sleepily stretched out for the enjoyment of the voyeuristic viewer. In other words, her passivity and the absence of male figures within the painting facilitated the viewer's fantasy of making himself the woman's lover" (4445). The depiction of sleep became a dominant theme of the Aesthetic movement. Sleeping women appear in late-nineteenth- and early-twentieth- 
century paintings by Frederick Sandys, Alfred George Stevens, Sir Edward Poynter, J. M. Strudwick, Alma-Tadema, and Sir Edward Burne-Jones. Lionel Lambourne notes that " $[\mathrm{o}] \mathrm{n}$ the whole, women are more often portrayed asleep than men. ... In sleep, problems of the relationships between men and women are postponed, so that the sleeping person for the viewer becomes an object of admiration or worship and physical involvement is sublimated" (195). The Briar Rose series, by Burne-Jones, the most prominent painter of what Robert Upstone calls "the second wave of 'High' PreRaphaelitism” (26), captures many a sleeping beauty. In one image, a chaste princess lies waiting for her suitor. Another picture produced for the series, Burne-Jones's more somber The Garden Court, depicts a woman with hidden face and body coiled in what seems to be anguish. In both BurneJones images, the maiden's restful pose delays her wakefulness and confirms the (imagined) male as the active, moving body in contrast to her beautiful passivity.

Rather than identifying with the kind of sleeping virgin memorialized by the PRB, Lily embodies a painting far more "awake" and empowering: a portrait of a lady by the academic painter the Pre-Raphaelite circle most vigorously denounced. Rossetti and his artistic brothers ridiculed Sir Joshua Reynolds, first president of the Royal Academy of Art and the artist who dominated the late-eighteenth-century British art scene, dubbing him "Sir Sloshua" for his sloppy, or "sloshy," artistic technique (Des Cars I5). In fact, one might think of Rossetti, founding father of the PRB, as a kind of anti-Reynolds, diametrically opposed to the "first father" of the Royal Academy. Reynolds is perhaps best known for fusing the "grand style" of the Italian masters-especially Raphael, Michelangelo, and the Venetian painters - into his portraits of the British aristocracy; he painted virtually every notable person of his time. The Fifteen Discourses (1769-90), a series of Reynolds lectures later published in book form, was for Wharton a formative influence, and she alludes to it with ease in her fiction. ${ }^{9}$ His emphasis on order and decorum informed Wharton's preference for a neoclassical style, evidenced in The Decoration of Houses, her well-received, coauthored interior decorating guide. Reynolds is the artist whose painting, The Age of Innocence, inspired the title of Wharton's 1920 novel. ${ }^{10}$ However the PRB might condemn the "sloshy" brush strokes of Reynolds's canvases, the artist cannot be accused of performing the kind of figurative seduction ${ }^{11}$ and enshrinement of the female subject Wharton obviously found to be a signature of the Pre-Raphaelites and their nineteenth-century heirs. 
The farthest thing from a Rossetti or a Waterhouse, Lily's tableau forms the literal and figurative center of Wharton's novel, and the painting with which she aligns herself sets her apart from her peers as well as the women of the early fiction. At the home of the Wellington Brys, Lily embodies Reynolds's portrait of Mrs. Joanna Lloyd (c. $1775-76)^{12}$ (see fig. I). Lily's tableau is very unlike the sort of melancholy maiden memorialized by the Pre-Raphaelites, who were quite fashionable at Lily's fin-de-siècle moment, given the 1897 opening and immediate success of London's Tate Gallery, which showcased British art and in the early years of the new century became known for its expansive collection of Pre-Raphaelite paintings. The unseemly Gus Trenor in fact encourages an alliance between Lily and a Pre-Raphaelite goddess when he says, all too familiarly, "By Jove, Lily, you do look a stunner!" (I46) - "stunner" being the Brotherhood's term for a strikingly beautiful woman. Nor is Lily's tableau inspired by a portrait of a female consumptive, a trope pervading nineteenth-century representations of women. Witness, by contrast, the images of pale, wan ladies disseminated by the PRB and by J. M. Whistler, who painted his ailing wife, as well as his model-mistress, laid up in bed. ${ }^{13}$ Representing women as convalescents in effect suspends them in time as female invalids. Reynolds's Mrs. Lloyd is not sleepily stretched out for the hungry voyeur: her body is vertical and grounded. She is the very picture of health and liberation. That the painting's date of completion, 1776 , coincides with American independence only emphasizes its spirit of emancipation.

It matters, too, that Reynolds's female subject flourishes in her natural setting. By contrast, women depicted outdoors in Pre-Raphaelite paintings tend to find themselves expiring or ensnared. Consider, for example, the alarmingly popular paintings of the drowning Ophelia, Lady of Shalott, and Elaine, ${ }^{14}$ or the claustrophobic female of Rossetti's The Day Dream (1880), a slouching, despondent beauty entangled in a tree. The liberation expressed in Reynolds's Mrs. Lloyd is amplified by the fact that she does not wear a crinoline, as a proper woman of Lily's day would do: rather, Reynolds has clothed his subject in a simple, free-flowing dress that accentuates her body. Her legs are provocatively crossed, her feet are sandaled, and her figure is abundant and voluptuous. She is far removed from the pale maiden replicated across Victorian visual culture.

Lily's tableau also stands in sharp contrast to the other "living pictures" on display at the Wellington Brys' soirée. Several tableaux, inspired by "old pictures" (2I5) and enacted by "fashionable women" (2II), precede Lily's 


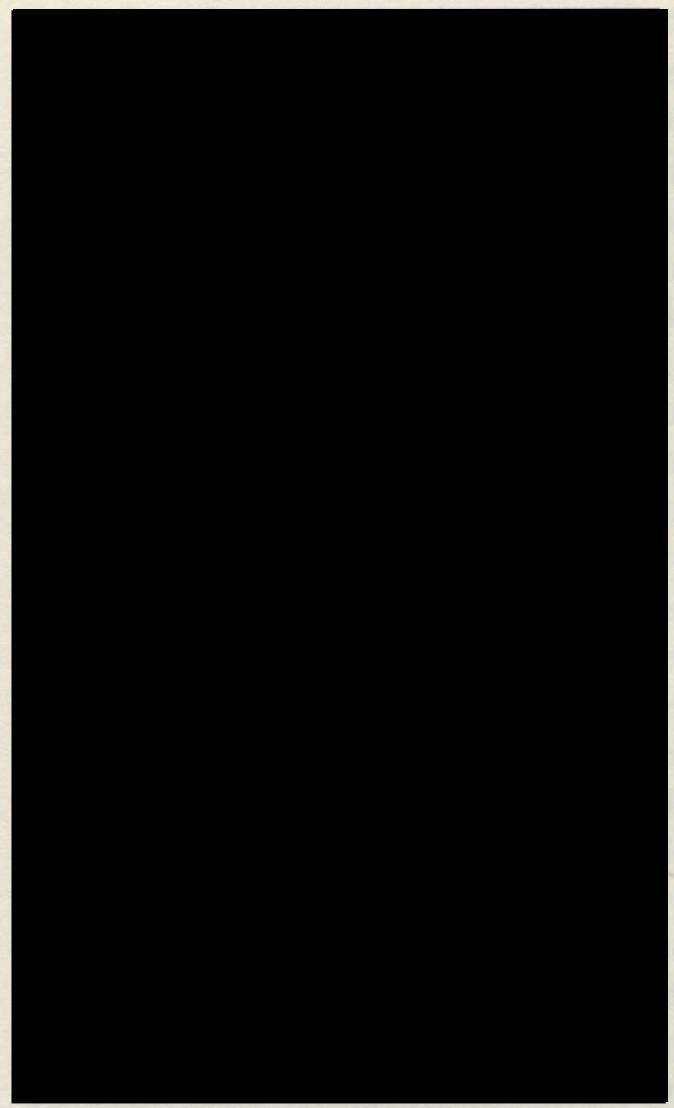

Fig. I. Sir Joshua Reynolds, Portrait of Joanna Lloyd of Maryland (c. 1775-76), Bridgeman-Giraudon/Art Resource, NY

performance. Wharton's playbill looks something like this: two ensembles of nymphs inspired by Botticelli and Angelica Kauffman; a "supper" drawn from Paolo Veronese; a playful group of "lute-playing comedians" by Watteau; a lady by Goya; Titian's painting of his daughter; and "a characteristic Vandyck [sic], in black satin" (214-16). These pictures, some of which are discussed further below, differ from Lily's insofar as they are generally the products of an earlier artistic tradition. Additionally, unlike the troupe of nymphs or musicians or the partakers of the supper by Veronese, Lily's tableau is notable for its depiction of a woman standing alone; rather than sharing the spotlight, she commands center stage. And unlike the other "one-woman-shows"- for example, Titian's daughter and the "typical Goya"-Lily does not rely on such props or accouterments as the tray 


\section{Picturing Lily $\propto 93$}

of fruit proffered by Titian's girl or the "exaggerated" and "frankly-painted" makeup worn by Carry Fisher as Goya's lady (215). Lily opts for elegant simplicity in her tableau. Further, those tableaux that capture a woman alone, such as the Goya or the Van Dyck, do so in a way that is far less liberating and empowering than Lily's Mrs. Lloyd.

Lily's reincarnation of Mrs. Lloyd could not be further removed from the Van Dyck tableau. Wharton notes that young Mrs. Van Alstyne's tableau "showed the frailer Dutch type, with high blue-veined forehead and pale eyes and lashes," making "a characteristic Vandyck, in black satin, against a curtained archway" (215). Wharton refers here to one of the artist's sumptuous portraits of noblewomen in elaborate black dress, Van Dyck's Portrait of a Flemish Lady (c. 1618), a picture of a woman bearing the high forehead, black satin, and "frailer Dutch type" described, whose ornate dress (elaborate jewelry, gold embroidery, lace cuffs, millstone collar) stands in striking contrast to Lily-as-Mrs. Lloyd (see fig. 2). The difference is even more pronounced when we note the bodily stiffness and sense of entrapment depicted in this Van Dyck. ${ }^{15}$ Where the Van Dyck suggests immobility, Lily's Mrs. Lloyd is all about mobility.

Wharton's juxtaposition of Lily's living picture alongside Carry Fisher's Goya-inspired tableau also speaks volumes. Wharton here invokes Goya's I790s portraits of the Duchess of Alba, the dark-haired Spanish beauty with whom he allegedly was romantically involved. In his 1795 image of the duchess, Goya curiously positions her standing stiffly, pointing downward in the direction of his signature (see fig. 3). A 1797 portrait, in fact, shows the duchess gesticulating toward the phrase "Solo Goya," etched upside down in sand by her feet, which at once suggests her heart is spoken for, while intimating, too, that what matters here is the artist's identity: only Goya. While the Goya painting thus emphasizes the male artist's authorship, as well as the female subject's status as "taken," Lily's tableau draws attention to Lily as artist and broadcasts her status as "available."

In contrast to the other living pictures, Wharton emphasizes the unadulterated beauty of Lily's tableau and in so doing again invokes George Eliot. Gerty Farish remarks on the appeal of Lily's "'simple dress'” (218), and Wharton's narrator notes that Lily "had purposely chosen a picture without distracting accessories of dress or surroundings" (2I6-I7), relying instead on her "unassisted beauty" (216). As Diane Price Herndl notes, "[s] he does not need decoration; she is decoration" (134). Wharton seems 


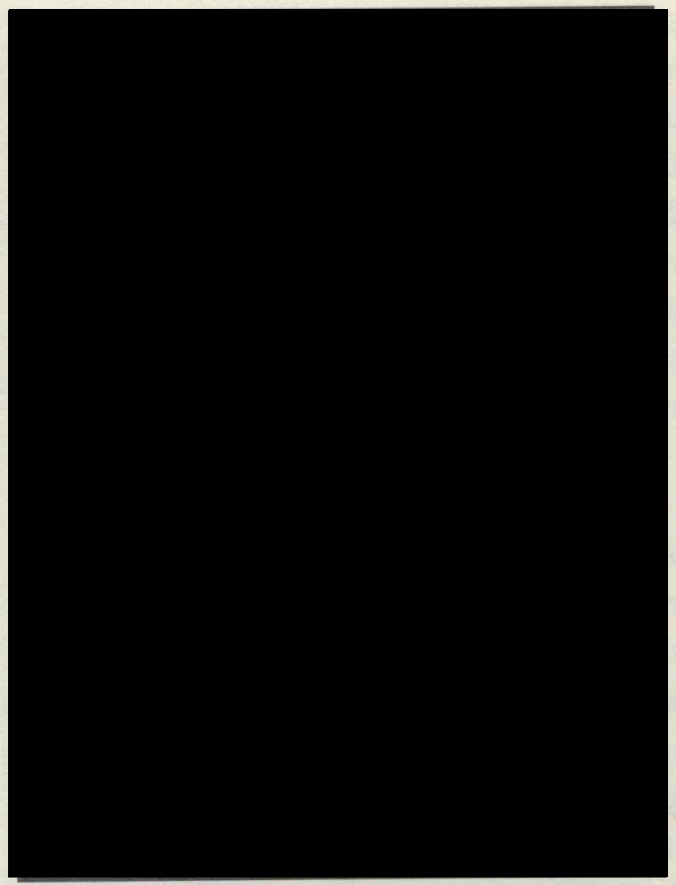

Fig. 2. Sir Anthony van Dyck, Portrait of a Flemish Lady (c. I6I8), Andrew W. Mellon Collection, Image (C) 2005 Board of Trustees, National Gallery of Art, Washington, DC

to have found a source in Eliot's Daniel Deronda, for in the earlier novel, Gwendolen Harleth, dressed for an archery meeting in Brackenshaw Park, is described in terms that anticipate Lily Bart's elegantly simple tableau: "it was the fashion to dance in the archery dress, throwing off the jacket; and the simplicity of [Gwendolen's] ... white cashmere with its border of pale green set off her form to the utmost. A thin line of gold round her neck, and the gold star on her breast, were her only ornaments. Her smooth soft hair piled up into a grand crown made a clear line about her brow. Sir Joshua would have been glad to take her portrait' (Eliot I:I19; emphasis added). Gwendolen's white cashmere with pale green border is echoed in Lily's "pale draperies, and the background of foliage against which she stood" (217). And if, as Eliot notes, no less than the Royal Academy president would have vied to paint Miss Harleth, Wharton's Lily is pleased to offer her body as a Reynolds. ${ }^{16}$

Just as Gwendolen Harleth's unassisted tableau had "set off her form to the utmost," the simplicity of Lily's tableau affords her male spectators an "exceptional opportunity for the study of the female outline," thus making 


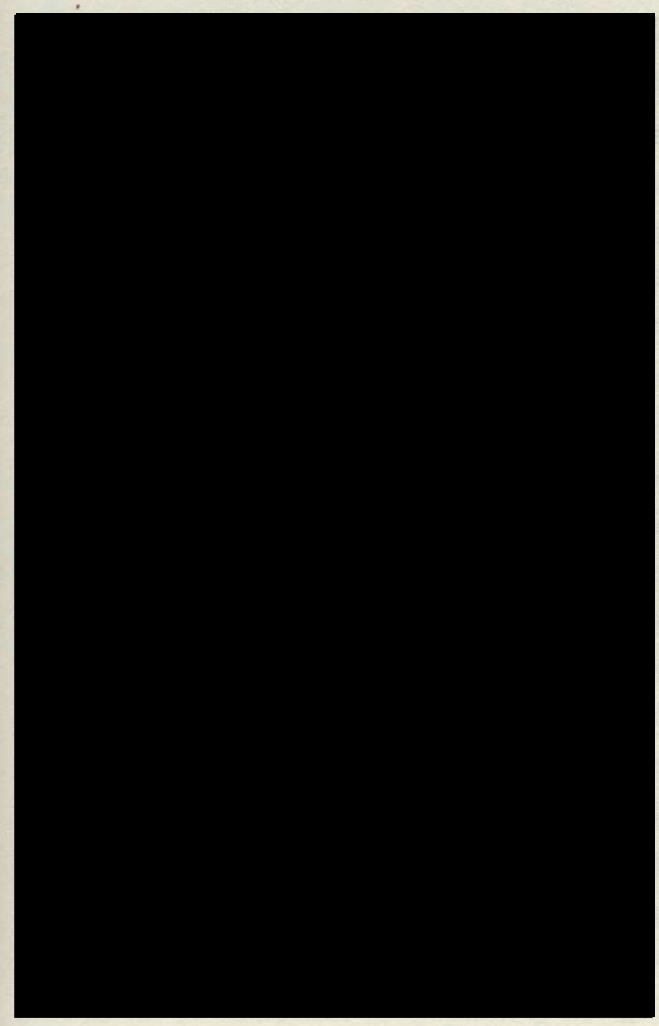

Fig. 3. Francisco de Goya y

Lucientes, Maria Teresa Cayetana de Silva, Duchess of Alba (1795), Scala/Art Resource, NY

hers the most provocative living picture in Wharton's gallery of human art (217). Even though the image Lily chooses for her tableau would not reveal as much flesh as the Botticelli or Kauffman tableaux, it is hers that attracts the most notice. As Judith Fryer notes, "[w] hat is different in this tableau is the frank presentation of Lily's body, an acknowledgment of an erotic nature that is never mentioned in her society, though its currents run deep beneath the surface" (Felicitous Space 77). So Lily, then, is putting her body into circulation - seemingly using her awareness of that undercurrent and trying to appeal to it in her viewers. Lily is markedly in control of what others see, for the lewd Ned Van Alstyne, whose wife poses as the heavily robed Van Dyck, remarks that while Lily had the nerve to "show herself in that get-up," " she presumably "'wanted [her viewers] . . . to know" "just how good she looked (2I7).

Quite paradoxically, Lily's tableau manages to represent Lily Bart more 
than Joanna Lloyd. Although Lily's tableau is a reincarnation of a Reynolds lady, it fails to eclipse her character: "[i]ndeed, so skilfully had the personality of the actors been subdued to the scenes they figured in that even the least imaginative of the audience must have felt a thrill of contrast when the curtain suddenly parted on a picture which was simply and undisguisedly the portrait of Miss Bart" (216). Lily's tableau, then, truly is a picture of Lily rather than a portrait of Mrs. Lloyd: "[s]he had shown her artistic intelligence in selecting a type so like her own that she could embody the person represented without ceasing to be herself" (216). This is more than a little problematic. Lily seems to be wrestling with the image of Reynolds's Mrs. Lloyd, and we have to wonder which will win. Will she be seen as an original ("the real Lily Bart" [217] Selden identifies in her tableau) or a reproduction of an eighteenth-century betrothed beauty? Can she at once embody Mrs. Lloyd and be herself?

Lily's tableau fails to eclipse her character because it is not her character but her body that is at stake here. Wharton's heroine objectifies herself, and she seems to understand that her aim is not so much to embody art as it is to use this occasion to sell herself as a marriageable commodity. Lily's objectification calls to mind what John Berger, in Ways of Seeing (1972), says of women's relationship to the gaze. Berger famously posits that "men act and women appear. Men look at women. Women watch themselves being looked at. . . The surveyor of woman in herself is male: the surveyed female. Thus she turns herself into an object-and most particularly an object of vision: a sight. ... [T] he 'ideal' spectator is always assumed to be male and the image of the woman is designed to flatter him" $(47,64)$. Surely, Wharton's Lily is all appearance, embodying what Laura Mulvey has called "to-be-looked-at-ness" (25). And the other women in tableaux are certainly watching themselves being looked at. Yet Lily complicates Berger's point, insofar as she at once appears ("women appear") and acts ("men act"): she is appearing and performing. To be sure, Lily is being looked at, relishing in the "triumph" (220) of her tableau and her status as the chief object of Selden's gaze. ${ }^{17}$ But a key distinction of Lily's tableau is her use of the medium to display her wares on the marriage market. Lily's tableau is more complex than the scenario Berger paints, insofar as Wharton, as author, is also a watcher, an orchestrator, a director of the scene she stages as the American Madame W[h]arton. So Wharton watches Lily watching men (and women) watch her. Evidently the "ideal spectator" is not always 
male. There is power in both spectating and speculating. Wharton's text, then, poses several important questions: How does Lily manage to achieve this power, however limited? How does she orchestrate the scene of her own objectification?

Although Lily ultimately becomes a figure in the service of art, for an art in the service of men, she draws power from her interactions with a portrait painter. In her self-choreographed tableau, Lily achieves more power than Wharton's earlier Mrs. Grancy of "The Moving Finger" (transformed into a portrait) or the Duchess at prayer (turned to a piece of statuary). In those early stories, men use art as a means to seduce or enshrine women, boasting, as does Mrs. Grancy's portraitist, that "you don't know how much of a woman belongs to you after you've painted her" (63I). In Lily's case, the female subject is the architect of her own tableau, in a way that she could not be in the earlier fiction. While Lily invokes the "organizing hand" of the portraitist Paul Morpeth (215), she manages the project of her objectification: " $[\mathrm{u}]$ nder Morpeth's guidance her vivid plastic sense ... found eager expression in the disposal of draperies, the study of attitudes, the shifting of lights and shadows. Her dramatic instinct was roused by the choice of subjects, and the gorgeous reproductions of historic dress stirred an imagination which only visual impressions could reach. But keenest of all was the exhilaration of displaying her own beauty under a new aspect: of showing that her loveliness was no mere fixed quality, but an element shaping all emotions to fresh forms of grace" (2II). While Lily is eager to channel her "vivid plastic sense" for her tableau, she rejects the invitation to be painted by Morpeth, who had mused on the "plastic possibilities" of her body, declaring "'gad, what a model she'd make!"” (382). When Carry Fisher asks Lily why she refuses to sit for Morpeth, Lily examines her face in the mirror with a "critical glance" and returns, "with a slight touch of irritation: 'I don't care to accept a portrait from Paul Morpeth'" (405). Lily, like Wharton-who, as an adult, resisted having her portrait taken - seems to recognize the power in the hands of image-makers, and this is a power she evidently is unwilling to relinquish. ${ }^{18}$

There is even more at stake in Lily's tableau. The narrative suggests that, in selecting the Reynolds portrait for her tableau, Lily enacts a kind of exorcism of the "dead beauties" that precede her in Wharton's fiction: "[i]t was as though she had stepped, not out of, but into, Reynolds's canvas, banishing the phantom of his dead beauty by the beams of her living grace. 
The impulse to show herself in a splendid setting — she had thought for a moment of representing Tiepolo's Cleopatra-had yielded to the truer instinct of trusting to her unassisted beauty, and she had purposely chosen a picture without distracting accessories of dress or surroundings" (216-17; emphasis added). The importance of Lily's having "banish[ed] the phantom" of Reynolds's "dead beauty" should not be underestimated. For while "dead beauties" are strewn about the early pages of Wharton's fiction, Lily chooses, in her tableau, to embody a different kind of beauty. Lily had decided against representing Tiepolo's painting of Cleopatra, a woman who, like Lily, displays powerful charm and allure, and, significantly, takes her own life. ${ }^{19}$ Cleopatra thus stands as a tragic, and not terrifically empowering, heroine to emulate. Had Lily chosen to embody the Egyptian queen, her living picture would have been more in keeping with the agenda of the PRB than the progressive representative act that it is. Lily is fully alive in her living picture and with her example Wharton also has exorcised the phantoms of the "dead beauties" killed into art in the early fiction.

Reading Lily's tableau within the context of Wharton's earlier "dead beauties" allows us more fully to appreciate the forward movement marked by Lily's living picture. In the early, eerie "The Duchess at Prayer," Wharton's description of the statue of the Duchess, commissioned by her jealous husband, troublingly suggests containment and confinement. While the face of Bernini's duchess is hidden, as if in shame, Lily-as-Mrs. Lloyd bears a face that is neither hidden nor enshrined, and certainly not in the way in which women were represented in Pre-Raphaelite paintings: Rossetti himself documents the impulse to enshrine women in art when the speaker of his 1870 poem titled "The Portrait" claims that "in painting her [he] ... shrined her face" (Collected Writings 185 ). Lily in a sense is the artist ${ }^{20}$ who remakes and reimagines Reynolds's Mrs. Lloyd. Lily is alive in her own artistic re-creation of her self. Wharton, then, in the staging of her tableaux vivants, shows us Lily at her most powerful.

And yet, as Elisabeth Bronfen has noted, Lily's tableau invites a series of complicated questions. We have to ask whether, for instance, the heroine "stages an appearance that has nothing to do with her, that reduces her to the medium of another's fantasies, or whether she uses this histrionic selfdisplay as her source of self-authorship, as the materialisation of her own fantasies? Is the unveiling of her body a disclosure of her sexuality or merely an appeal to her masculine viewer's sexual fantasies?" (282). How, 
then, does Wharton reconcile the central tension in Lily's tableaw - the heroine's use of self-display as self-authorship vis-à-vis her complicity with a pernicious tradition that feverishly objectifies women? Jack Stepney likens Lily's tableau to "'a girl standing there as if she was up at auction"” (254), and Rosedale responds to Lily's living picture with " ' $[\mathrm{m}] \mathrm{y}$ God, ... if I could get Paul Morpeth to paint her like that, the picture'd appreciate a hundred per cent in ten years" (255). Lily works toward the kind of "self-authorship" to which Bronfen refers, by means of her living picture. But Lily has at least two strikes against her. First, Selden, through whose eyes Lily is most often presented, exposes himself as an untrustworthy reader and thus proves ill-equipped to see the full "picture" of Lily Bart. Second, Lily is unwilling to make the ultimate compromise-lower the price of her body on the marriage market - in order to remain alive. These two circumstances precipitate her defeat.

Revisiting Wharton's description of Lily's tableau allows us to see an important way in which Selden fails to get the full picture of Lily. In her account of Lily's living picture, which is filtered through Selden's gaze, Wharton withholds a crucial detail of the Reynolds painting. Reynolds's Mrs. Lloyd is engaged in the act of writing, and this has encouraged readers to envision Lily as a kind of woman writer. ${ }^{21}$ Sir Joshua's Mrs. Lloyd carves her married name on the trunk of a tree, in keeping with a trope found in Shakespeare's As You Like It and popularized in eighteenth-century paintings by Boucher, Tiepolo, and Benjamin West. Reynolds's interpretation of the tree-writing motif is all the more progressive when we consider that, traditionally, the figures are depicted as reclining or seated (Mannings 309). His Mrs. Lloyd seems more interested in her creative act than in the implied audience's gaze, suggested by the fact that her face appears in profile. Wharton's account makes no mention of a pen in Lily's hand; her readers would have to be familiar with the Reynolds painting, and likely many of them were, to appreciate the reference to a woman writing. Although we cannot be sure Lily holds the pen, we also cannot be sure she does not. What matters is that Selden's gaze fails to record it. The image is filtered through a narrative lens that moments before is described as informed by Selden's predilection for "vision-building" which "lead[s] him so far down the vistas of fancy" (2I6). Earlier in the scene we are warned that "Selden's mind ... could yield to vision-making influences as completely as a child to the spell of a fairy-tale" (215), and moments after Wharton 
comments on Lily's tableau, which is colored by Selden's view of her (2I7), he is "roused" from this reverie by his cousin's interruption (218). As she later would do in The Custom of the Country and The Age of Innocence, Wharton compels us to mind the gap between the female subject and the male narrative gaze through which she is presented.

Despite the fact that Lily is perfectly alive in her tableau, Selden identifies in her a disempowering posture that harkens back to Wharton's kneeling, repentant Duchess at prayer. Gazing at Lily's living picture, Selden "feel[s] the whole tragedy of her life" (2I8) in a way that aligns Lily with the "frozen horror" of the silenced heroine of "The Duchess at Prayer" (154). Reading Lily's tableau, Selden imagines that "her beauty, thus detached from all that cheapened and vulgarized it, had held out suppliant hands to him from the world in which he and she had once met for a moment" (2I8; emphasis added). Wharton again rewards us for reading Lily alongside her predecessors, for no matter how much agency Lily achieves in her artistic re-creation, Selden sees in her a helpless pose that strikingly recalls the suppliant, clasped hands of the doomed Duchess "locked in prayer before an abandoned shrine" ("Duchess at Prayer" 153). Indeed, one might infer from Selden's reading that Lily had chosen for her tableau not Reynolds's Mrs. Lloyd but something more akin to Rossetti's Beata Beatrix (Blessed Beatrice) (1864-70), a painting that aestheticizes and sexualizes the death of Dante Alighieri's beloved (see fig. 4). ${ }^{22}$ And Selden's morbid reading of Lily anticipates her own status as a body-made-shrine at the narrative's end. While the reader may wish to credit Selden for his ability to penetrate the vision of Lily's tableau and see there "the whole tragedy of her life," his awareness does not pardon him for failing to come to Lily's aid in her most critical hours. In fact, considering his gift of insight into her predicament, his failure to act on her behalf is all the more indefensible.

If Wharton's Lily is fully alive and empowered in her tableau, she ultimately becomes the "dead beauty" she had successfully banished from her "living picture." The novel's closing scene captures Selden at the deathbed of his (would-be) beloved, and Wharton's use of this trope allows her to critique a tradition, manifest in the work of Rossetti and his Pre-Raphaelite brothers, that positions dead beautiful women as subject to the gazes of men who fail to rise to their occasion. Visual images of this sort freeze an aesthetically appealing woman into a posture that is disempowering, passive, and forever to-be-looked-at while immortalizing the male in the active 


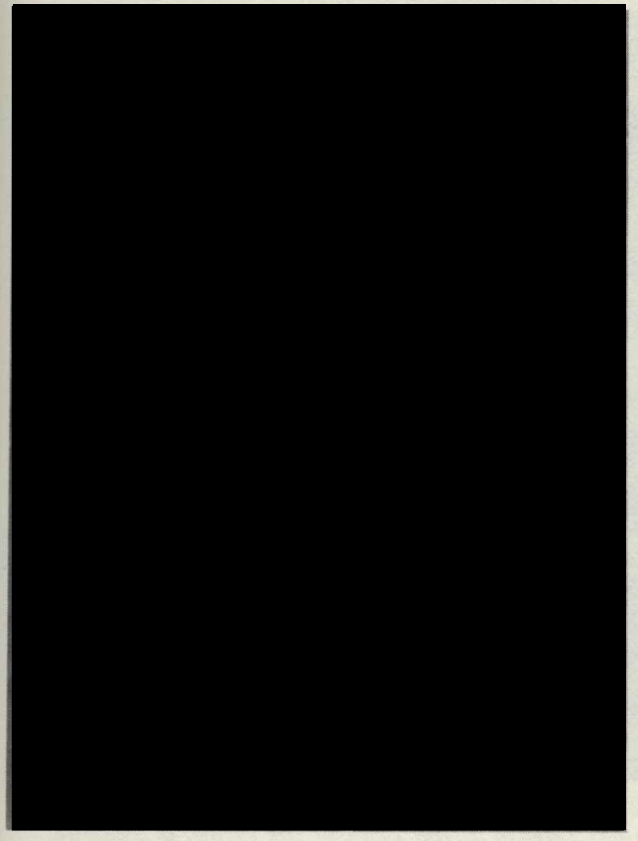

Fig. 4. Dante Gabriel Rossetti, Beata Beatrix (1864-70), (C) Tate, London 2005

position as gazing consumer. Wharton invokes such images as Rossetti's Dante's Dream at the Time of the Death of Beatrice (1856) (see fig. 5). The painting depicts Dante Alighieri, for whom Rossetti was named, approaching the deceased Beatrice laid out on her burial bier. John Nicoll notes that Rossetti in this image adapts a theme from the other Dante in which the poet "is led by [the god of] love ... to see the dead Beatrice laid on a bier. Attendants lower a pall laden with symbolic mayflowers, while poppies symbolizing death litter the floor" (149). Rossetti painted two versions of this scene, a watercolor in 1856 and an oil painting in $187 \mathrm{I}$; in each he has imposed onto the face of Beatrice the features of the object of his affection. In the 1871 image, we recognize Jane Morris, the inaccessible raven-haired beauty memorialized in such allegorical Rossetti paintings as Proserpine (1874) and The Day Dream (1880) and in the sonnet sequence The House of Life (1870). In the 1856 image, we find Rossetti's wife, Elizabeth Siddall, who died in $1862 .{ }^{23}$

Wharton may have found a source for Lily's untimely death in the apparent suicide of Elizabeth Siddall. ${ }^{24}$ Lizzie Siddall is perhaps best known for her aesthetically beautiful deaths, having famously posed for John 
Fig. 5. Dante Gabriel Rossetti, Dante's Dream at the Time of the Death of Beatrice (I856), (C) Tate, London 2005

Everett Millais's Ophelia. The similarities between Rossetti's muse and Wharton's heroine are striking. Both Lily and Lizzie were transformed, in life, into works of art, ultimately serving as a beautiful corpse subject to the gaze of what Rossetti, in The House of Life, calls "a belated worshipper" (Collected Writings 3II), and a remorseful one at that. Each woman died after a gradual physical decline: Lily departs the novel slighter and less voluptuous than when we met her, while Lizzie apparently suffered from pulmonary consumption and was thought lovelier for her "raggedness." 25 Both women endured sleeplessness, dying, at around age thirty, of an overdose which may have been accidental. (Lily's drops were chloral while Lizzie's were laudanum; both acquired a dependence on the drug in hopes of escaping an unbearable consciousness.) Of Siddall's death, Nicoll writes, " $\mathrm{t}]$ he evidence is confusing, but it seems more likely than not that she killed herself as a result of her melancholia and the increasing pain of her illness. Whether by accident or design the cause of death was an overdose of laudanum. In spite (or perhaps because) of the personal devastation which Rossetti suffered, and the remorse with which he never ceased to 
reproach himself, Elizabeth Siddal[1]'s death provided the personal impetus that was perhaps necessary if the impending changes in his art were to become fully worked out" (127, I32). Siddall's death fueled Rossetti's relentlessly necrophilic painting and poetry. And Rossetti's now legendary burial of his poems in his wife's coffin, and subsequent recovery of the manuscript by disinterment (an act that perhaps explains his worship of Poe), emphasizes his blurring of the lines between art and necrophilia. Rossetti's numerous renderings of Lizzie as dead, dying, or martyred (Beatrice, Ophelia, Saint Catherine) permanently enshrine her as an eroticized beautiful corpse laid out for our visual consumption. Turning to the example of the Rossetti-Siddall connection helps us step outside The House of Mirth and appreciate Wharton's concern with something much larger than the tragedy of a fictional Lily Bart. She is commenting on a historical reality of women who, despite the fact that they may be aspiring artists-Siddall, a gifted painter and poet, is a case in point-are nevertheless fetishized, sexualized, worshiped in art, and ultimately driven to their tragic deaths by a culture that prefers to imagine them as beautiful corpses.

Further connections can be drawn between Rossetti's work and Wharton's novel through the image of lilies, which played an important role in Rossetti's iconography and which Wharton invokes in The House of Mirth. Rossetti's I870 poem "Love-Lily" appeared in The Collected Works, which Wharton owned, and in 1884 was set to music by the celebrated musicologist Edward Dannreuther. "Love-Lily" is spoken in the voice of an admirer who equates a woman (and particularly her body parts) with a lily, marveling at her physical virtues with his "gazing eyes" (Collected Writings 255). Rossetti's 1874 painting titled Sancta Lilias (Holy Lily) features the central female figure of The Blessed Damozel holding irises (see fig. 6). Rossetti produced a chalk drawing by the same name (1879) depicting a haloed woman holding a stemmed lily in her left hand. A ribbon inscribed with the phrase "Aspice Lilias" (gaze at the lily) extends from the lily, around which it is wrapped (McGann). Wharton shares a verbal as well as a visual lexicon with Rossetti. He begins his sonnet sequence, The House of Lifewhose title Wharton echoes with The House of Mirth-thus: "A Sonnet is a moment's monument" (Collected Writings 275); Wharton's working title for her 1905 novel was "A Moment's Ornament."

Wharton's final scene, which is at once monumental and ornamental, responds to the visual precedent of Rossetti's Dante's Dream at the Time of 


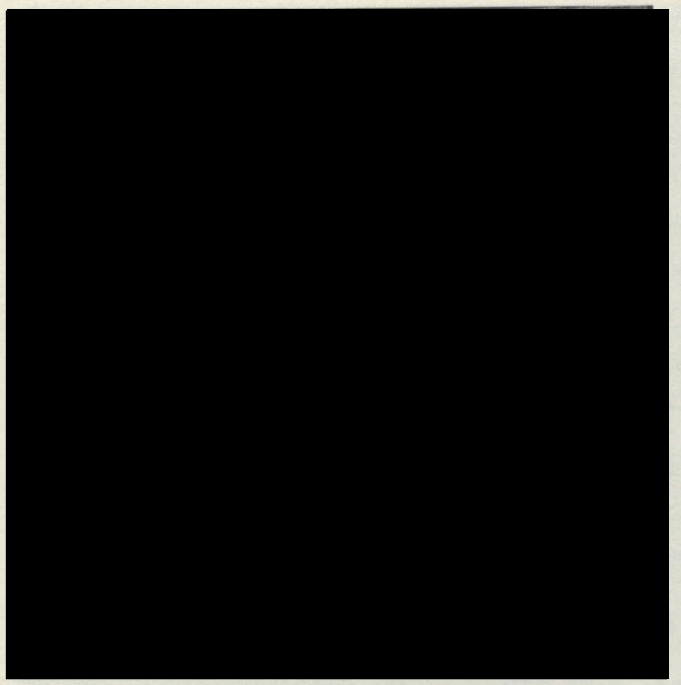

Fig. 6. Dante Gabriel Rossetti, Sancta Lilias (1874), (C) Tate, London 2005

the Death of Beatrice. Like Dante Alighieri in Rossetti's painting, Selden is "led by love" to see his beautiful, dead beloved-if not by love, then at least by hope. Selden had awoken to "a promise of summer in the air" that reflected his own sense of "intoxication" (523) and "youthful... adventure" ( 524$)$. But this, of course, is a day after he fails to rise to the occasion and abandons Lily in a state of despair; as they part, he finds himself "still groping for the word to break the spell" binding his "faculties" (502). And now, a day late, he rushes to her boardinghouse with "the word he meant to say to her" which "could not wait another moment to be said" (524). Wharton's description of Selden beholding the deceased Lily poignantly conjures up the Rossetti painting: "[h]e stood looking down on the sleeping face which seemed ... like a delicate impalpable mask over the living lineaments he had known.... [H]e stood alone with the motionless sleeper on the bed. ... [H]e felt himself drawn downward into the strange mysterious depths of her tranquility" ( 526,528 ; emphasis added). Dante Alighieri's Vita Nuova, which served as the source for Rossetti's painting, records the poet's vision of the death of Beatrice with a macabre voyeurism that looks forward to Wharton's finale:

Then Love said, "Now shall all things be made clear Come and behold our lady where she lies." 


$$
\text { Picturing Lily } \propto 105
$$

These 'wildering phantasies

Then carried me to see my lady dead.

Even as I there was led,

Her ladies with a veil were covering her;

And with her was such very humbleness

That she appeared to say, "I am at peace." (qtd. in Upstone 79)

Dante's assurance that, with Beatrice's death, "shall all things be made clear" is eerily echoed in the last line of The House of Mirth, which observes that between Selden and the departed Lily "there passed ... the word which made all clear" (533). Selden, studying "[t]he mute lips on the pillow," had been drawn "penitent and reconciled to her side" (532), aware of "his cowardice" (530), which cost him his love and accounts for his "having failed to reach the heights of his opportunity" (532). This closing moment poignantly recalls Wharton's opening scene, which describes Selden's recognition of a similar "mask" on Lily's face: "[s]he stood apart from the crowd, ... wearing an air of irresolution which might, as he surmised, be the mask of a very definite purpose" (3). But, sadly, Lily ultimately will wear the mask of death subjected to Selden's wistful gaze as the lady has become a beautiful corpse. Terence Davies's film amplifies Wharton's link between art and necrophilia by having his camera dwell on Gillian Anderson's dead Lily Bart laid out on her bed, with Eric Stolz's remorsefully gazing Selden grasping her motionless hand. The image furnishes the backdrop on which the credits roll and as such invites us to participate in the act of objectifying a female corpse.

How, then, do we reconcile Lily's vibrant, Reynolds-inspired "living picture" with her final presentation as a still life? If Lily so seamlessly frames herself as a liberated, empowered Reynolds lady, why then does "Madame Wharton" lay her body out as a corpse, subject not only to Selden's gaze but to our own? Lily achieves agency in her objectification in a way her predecessors could not. Her problem, however, seems to be her unwillingness to compromise. But what, after all, is a girl to do? Lily might use Bertha Dorset's incriminating letters to restore her reputation and financial situation. Further, Lily might accept the other options available to her (for example, Rosedale, George Dorset, even Gus Trenor), which, however distasteful, would spare her from utter destitution. Lily chooses not to stoop.

If it is impossible for Lily to remain alive in this narrative, Wharton 
finds a way for Lily's younger literary sisters, the women of the new century, to thrive in the later narratives by feeding and rewarding their desire to display themselves as objets d'art. In the later pages of Wharton's oeuvre, which are not decorated with the "dead beauties" that crowd the early fiction, Wharton sets the stage for the likes of Undine Spragg of The Custom of the Country and Bessy Paul of "The Temperate Zone" - shameless material girls who bend and ply the portraitist's hand to their own marketing purposes. For instance, Undine, perhaps better than Lily, understands the politics of representation, and she seems to have drawn inspiration from John Singer Sargent's Mrs. Ralph Curtis for the full-length portrait whose production she oversees. Like the 1898 painting by Sargent, whose little black book was something of a Who's Who for Wharton's set, Popple's portrait of Undine depicts a firmly grounded, flame-haired, self-possessed beauty in haute couture confronting the viewer head on. Wharton, then, transplants her Lily to a later hour in modern-day New York and equips her, in the sleek shape of Undine and her literary sisters, with the tools to survive. Like Lily, these modern women enact a kind of body art and oversee the way in which they are represented in visual culture, but they reach further and in so doing manage to escape the nineteenth-century conflation of art and necrophilia. This survival, of course, will continue to involve compromise, a specter that looms wherever Wharton interrogates the sexual politics of representation.

\section{Notes}

Several cherished colleagues from the University of Maryland lent their kind eyes and ears to this essay, and it is with pleasure that I acknowledge them here: Jaime Osterman Alves, Tara Hart, Robert S. Levine, Marilee Lindemann, Elizabeth B. Loizeaux, Nels Pearson, and Catherine Romagnolo. Jill M. Kress and Gary Totten generously offered helpful suggestions throughout the revision process. For assistance in reproducing the illustrations I thank Alison Fern and Robert Upstone at Tate Britain, John Benicewicz at ArtResource, and Peter Huestis at the National Gallery of Art. For permission to print this article, an extended version of which appeared in Edith Wharton and the Visual Arts (2007), I thank The University of Alabama Press. This essay is dedicated to the memory of Janice Thaddeus, who years ago read and heartily responded to my earliest analysis of The House of Mirth. Her example continues to inspire.

I. Maureen Montgomery notes that at the start of the twentieth century, when Wharton's novel is set, photographs became a popular means of disseminating images of women in the press (59). 
2. Selden admiringly studies Lily as a painting: in a private moment, Lily leans forward, and " $[\mathrm{a}] \mathrm{s}$ she did so, he noted, with a purely impersonal enjoyment, how evenly the black lashes were set in her smooth white lids, and how the purplish shade beneath them melted into the pure pallour of the cheek" (I4-15).

3. Insofar as she steps into, and not out of, a painting, Lily does precisely the opposite of what Terence Davies says of Gillian Anderson. In a 14 January 200 interview with Sharon Waxman in the Washington Post, Davies admits he cast Anderson as Lily Bart in his recent film of The House of Mirth because she reminded him of a Sargent painting (Waxman).

4. See essays by Cynthia Griffin Wolff ("Lily Bart and the Beautiful Death"), Judith Fetterley, Joan Lidoff, and Elaine Showalter ("The Death of the Lady [Novelist]").

5. Maureen Montgomery uses the example of Lizzie Hazeldean to point to Wharton's critique of a culture that compels women to prostitute themselves: "[i]n representing Lizzie's choices in this way, Wharton indicts old New York for condemning women to a position of dependency. ... [She] call[s] into question the nature of marriage in such a society. Is not marriage itself a form of prostitution when so little choice is afforded women?... [A] society that prides itself on honor and respectability but that allows women little opportunity to provide for themselves bears responsibility for the prostitution of women" (37).

6. McCullough traces the history of this term by pointing to the advertisements for Dr. Collyer's series of tableaux, which debuted in New York at the Apollo Rooms in I847: " $[w]$ hen he opened at the Apollo Rooms the term, 'model personifications,' was used to designate his performances. As the run progressed the newspapers used 'living statuary,' 'model impersonations,' and 'living models' to describe the production. In his advertising, Collyer consistently used the term, 'model artistes.' ... When editors and other writers picked up the term, they dropped the last 'e,' stripping away the hint of French. 'Model artists' then became the common title for this kind of production and for the performers themselves. Furthermore, these entertainments were looked upon as 'exhibitions' rather than as acts or performances or shows" (23). Living pictures appear in nineteenth-century American fiction by Nathaniel Hawthorne, Oliver Wendell Holmes, and Louisa May Alcott. For an excellent discussion of tableaux vivants in American fiction and culture, see Mary Chapman.

7. See McCullough 43-44 (figs. 8 and 9) for a reproduction of the playbill. Special thanks are due to Jack McCullough for pointing our attention to Madame Warton.

8. Maureen Montgomery quotes the response that these "living pictures" on Bowery stages evoked from the Town Topics columnist known as "the Saunterer": "[a]t present the youth of New York may gaze each night in the year upon female nakedness presented in the most tempting and sensual shape that ingenious men can devise. Under the name of art the most amazing visions of living, breathing, palpitating nudity... [are] deliberately spread before innocent eyes, and the moral damage thereby is, I maintain, beyond computing" (2).

9. George Ramsden lists Reynolds's Fifteen Discourses (1820) among the surviving texts in Wharton's library, and Wharton refers to the Discourses in her novella False Dawn. The Discourses preached many of the principles rejected by the PRB. Reynolds 
asserted that the "genuine painter, ... instead of endeavouring to amuse mankind with the minute neatness of his imitations, ... must endeavour to improve them by the grandeur of his ideas; instead of seeking praise, by deceiving the superficial sense of the spectator, he must strive for fame, by capturing the imagination" (qtd. in Penny 30). Reynolds argued that the great artist must, in his words, be more than a "mere copier of nature," but instead improve upon it (qtd. in Penny 32). As John Nicoll notes, like William Blake before him, Rossetti "found himself profoundly out of sympathy with the murky tones and contrived highlights of the imitation [of] old masters which Reynolds' advocacy of the 'grand style' had popularized" (22).

IO. This Reynolds painting captures a fancily dressed young girl with hands crossed demurely over her chest. Like the painting Lily reenacts in her tableau, this portrait of a (young) lady also depicts the female in profile-like Mrs. Lloyd, the girl's attention seems diverted - and it places her in a natural setting which seems to have served Reynolds as a comfortable, liberating space for females.

II. The connection between the Pre-Raphaelites and the idea of art as a sexual conquest is underscored by the initials "P. R. B.," with which these paintings were signed. The monogram ostensibly stood for the "Pre-Raphaelite Brotherhood" shared among the seven male artists who organized a collective in the late 1840 , but was playfully translated by their contemporaries as, among other things, "Penis Rather Better" (Des Cars 23), an appellation that startlingly admits that, for these young artists, anatomy was inextricably linked to the process of artistic creation.

12. Reynolds's Mrs. Lloyd was exhibited at the Royal Academy in 1776 under the title Portrait of a Lady, whole length. It commemorates the marriage of Joanna Leigh, daughter of John Leigh of England's Isle of Wight, to Richard Bennett Lloyd of Maryland (1775) and was painted c. 1775-76 (Mannings 309). Nicholas Penny asserts that "[t]he lady he depicted writing the name Lloyd on a tree was Mrs. Lloyd by the time the painting was exhibited, but surely still Miss Leigh when she sat to Reynolds" (29); Mannings, however, notes that the portrait was painted after the engagement if not after the wedding. (One cannot be sure, as Reynolds's Pocket Books for $1774-76$ are missing.) During Wharton's lifetime, the painting was exhibited at the Royal Academy in 1873 and 1887 (Penny 276); it is possible Wharton viewed it in person then or had access to it by way of its numerous copies. Terence Davies's recent film adaptation departs from the novel when his Lily enacts a tableau vivant of Watteau's Summer. To the (otherwise beautifully adapted) film's detriment, the camera focuses but a fleeting moment on this scene despite the fact that it is the literal and metaphorical center of Wharton's novel.

13. See, for example, Whistler's The Artist's Model Maud Reading in Bed (1886) or Note en Rouge: La Sieste (Harmony in Red: The Siesta) (1884), both of which depict the artist's mistress, Maud Franklin.

14. John Atkinson Grimshaw's Elaine (1877) and The Lady of Shalott (1878) serve as illustrative examples. Though not a card-carrying member of the Pre-Raphaelite Brotherhood, Grimshaw's paintings share with his contemporaries a fascination with the idea of a recumbent dead lady. For more on this trope, see Diane Price Herndl's Invalid Women. 
15. Art historians have called the Portrait of a Flemish Lady a traditional Van Dyck. As a possible source for the Van Dyck in Wharton's novel, Judith Fryer reproduces Van Dyck's Henrietta Maria with Her Dwarf(1633), which is in fact a Van Dyck in blue satin. With the great exception of Fryer, heretofore the scholarship on this novel has not pursued the sources for the other paintings Wharton has carefully chosen for this scene nor has it considered them in contrast to Lily's tableau. Helen Killoran's important Edith Wharton: Art and Allusion briefly examines Lily's tableau but does not discuss the other living pictures $(25-26)$. Fryer reproduces several images as possible sources but does not at length discuss them in contrast to Lily's tableau ("Reading Mrs. Lloyd" 34).

16. The images of archery and youthfulness in this excerpt from George Eliot also anticipate Wharton's May Welland, who is repeatedly aligned with the goddess Diana in The Age of Innocence, particularly in the archery scene. We find, then, in Daniel Deronda, more evidence of the intertextuality of Wharton's oeuvre. Judith Fryer also finds a literary precedent in Daniel Deronda, noting that Gwendolen impersonates Saint Cecilia for her tableau vivant; Fryer does not discuss Gwendolen's pose as Hermione, nor does she point to the scenes here invoked ("Reading Mrs. Lloyd" 29).

17. After the tableaux are complete, Lily "read, too, in his answering gaze the delicious confirmation of her triumph, and for the moment it seemed to her that it was for him only she cared to be beautiful" (220). Selden had seated himself as a spectator at the Welly Brys' home, "surveying the scene with frank enjoyment" (2I2).

I8. See Wharton's I4 February 1902 letter to William Crary Brownell, in which she voices her reluctance to be photographed (Letters 57-58). Wharton was painted on only a few occasions in her lifetime and did not enjoy the experience (Benstock 63).

19. Giovanni Battista Tiepolo, Venetian, Italian rococo artist of the eighteenth century, painted several images of Cleopatra, the most famous of which is the fresco The Banquet of Antony and Cleopatra (c. 1745-50), in which she slips a pearl into her drink (Morassi plate 46, 49).

20. Wharton offers ample material to support a reading of Lily as a metaphorical artist. Selden, for instance, tells her "[y] our taking a walk with me is only another way of making use of your material. You are an artist and I happen to be the bit of colour you are using today" (IOS). See Amy Kaplan's discussion of Lily's artistic sensibilities in The Social Construction of American Realism.

2I. For instance, in Edith Wharton's Letters from the Underworld, Candace Waid argues that Lily becomes a writer when she impersonates Mrs. Lloyd; Elaine Showalter ("Death of the Lady [Novelist]"), Walter Benn Michaels, and Judith Fryer ("Reading Mrs. Lloyd" and Felicitous Space) also focus on the detail of the pen-in-hand.

22. This particular Rossetti painting evidently meant a great deal to Wharton, as she wrote an ekphrastic poem titled "The 'Beata Beatrix' of Rossetti"; this unpublished poem is part of the Wharton papers at the Lilly Library, Indiana University, and, though it is undated, the bound volume of manuscript poems in which it appears contains various dates indicating that the verse may have been composed between 1889 and 1893 . The painting captures Rossetti's wife, Elizabeth Siddall, as Beatrice at the moment of her death. In a letter, Rossetti noted that "the picture ... is not at all intended 


\section{IIO $\propto$ Orlando}

to represent Death ... but to render it under the resemblance of a trance, in which Beatrice . . . is suddenly rapt from Earth to Heaven" (qtd. in Wilton and Upstone I55). As Andrew Wilton and Robert Upstone have noted, Rossetti's Beatrice "is frankly depicted in a way that resembles sexual ecstasy. Her facial expression, raised head, straining throat and parted lips are overtly sensual, and Rossetti evidently intends to suggest a connection between the sexual and the divine, between orgasm and revelation" (156).

23. Wharton may have seen the 1856 watercolor at the Burlington Fine Arts Club in $\mathrm{I} 88 \mathrm{I}$, the New Gallery in 1897 , or the Tate in 1923 (McGann).

24. As Rossetti's brother, William, noted, Dante Rossetti insisted on spelling her name "Siddal" (I7InI). As Griselda Pollock notes, "'Siddal' is thus claimed for Rossettithere is possession in naming" (I00). And just as there is possession for Rossetti, so, too, for Wharton's Rendle, of "The Muse's Tragedy," who renames Mary Anerton "Silvia" in his sonnet sequence (77).

25. The Pre-Raphaelite painter Ford Madox Brown once described Rossetti's ailing wife as "looking more ragged and more beautiful than ever," a remark that betrays the Brotherhood's predilection for sickly, frail women (Pearce 53). 